\title{
Into the Feline Umwelt: An Exploration of Eliot and Shawqi's 'Mind-style' Conceptualization of Cats
}

\section{Olfat Nour El-Din}

Assistant Professor, Faculty of languages, October University for Modern Sciences and Arts (MSA), Egypt.

\begin{abstract}
In the past, people thought that earth was the center of the universe. More recently, people think that they are the most important on Earth. These speculations raise the question: why do humans have this subjective view of the world? Uexküll's (1934) theory of the umwelt provides a very reasonable answer. To Uexküll, each species perceives the surrounding world in a way that agrees with their perceptive abilities and their interests. Accordingly, people are oblivious to other parallel umwelts that exist beyond their borders. One umwelt they are oblivious to is that of the animals. However, writers across the ages have tried to depict animals' lives in their narratives. Based on Uexküll's theory, these accounts carry subjective views. In this regard, the current study attempts to examine two poets' views of the feline umwelt. T. S. Eliot and Ahmed Shawqi are celebrated poets who belong to the same age; by comparing their conceptualization of the feline umwelt, much can be revealed about their subjective views on the one hand, and how these views are influenced by cultural ideologies, on the other. To conduct the analysis, Leech and Short's (2007) stylistic approach to 'mind-style' is adopted, integrating some tools from Leech (1991) to spotlight some of the poetic devices employed in the poems. The study concludes that Shawqi and Eliot adopt many similar tools in their depiction of the feline umwelt; however, their overall depiction differs, which proves that their account of the feline umwelt is subjective and is bound to cultural influences.
\end{abstract}

Keywords: Comparative Stylistics, Poetry, Cultural Influence, Umwelt, Mind-style, T. S. Eliot, Ahmed Shawqi 
"The subject builds his world according to his basic needs and action tools" (Berthoz, 2009, p.17).

\section{Introduction}

Humans perceive the world in a way that agrees with their needs and abilities. Berthoz (2009) argues that "the 'projective brain' is a simulator and an emulator of reality that builds its perceived world according to its planned acts" (p.17). Accordingly, people are prisoners of their subjective perceptions of the world, their umwelt. 'Umwelt' is a German word that can be translated as 'environment'. However, after Uexküll's seminal introduction of the notion of the umwelt, the term has become associated with the perceived world.

Uexküll (2010) observes that "the gateway to the environments, for everything a subject perceives belongs to its perception world [Merkwelt], and everything it produces, to its effect world [Wirkwelt]. These two worlds, of perception and production of effects, form one closed unit, the environment." (p.42). That is, humans perceive the world around them in a way that serves their needs and fits their agenda. In this regard, Singer (2009) states that the human brain is constrained, for it relies only on "primary perception" and on "deriving inferences from observables" (p.40). That is, humans see what they can see and what they need to see, which means that most people are oblivious to the big universe with all the riches it contains. Pollman (2013) further comments "For Uexküll, there is no common ground, there is no common world, for every species (and, potentially, every individual) perceives the world differently and, as a result, lives in a world that is different from that of other living beings" (p.778).

Herman (2016) links Uexküll's concept of the umwelt to "the narrative modelling of nonhuman subjectivity" in attempt to "examine the ways in which narratives project animal worlds" (p.54). He argues that such narratives present accounts of worlds that lie beyond human boundaries of conceptualization. To conduct his study, Herman (2016) adopts a cognitive approach to examine how animals are represented in narratives integrating Fowler's concept of 'mind-style'.

Fowler (1977) first coined the term 'mind-style' to refer to the linguistic patterns that "give rise to an impression of a 'world-view' associated with a character or a narrator" (p.76). It is important to note that Fowler's concept of 'mind-style' is inspired by Halliday (1971) who offers clear insights on how fictional narratives introduce different characters with different mindsets. Leech and Short (2007) build on Fowler's premise of mind-style in their seminal work Style in Fiction (first published in 1981). They argue that literary texts present a fictional world that captures a writer's understanding of the real world. Accordingly, any "conceptualization of a world presupposes both a world to refer to, and a mind through which that world is reflected" (Leech \& Short, 2007, p.150). This link between the world-view and the mind can be traced through the writer's stylistic choices. To this end, Leech and Short present lexico-grammatical tools that aim at revealing semantic associations and interpretations of a writer's mind-styles.

With the advent of cognitive linguistics, mind-style was approached from a cognitive perspective. Some early cognitive poetic approaches of mind-style integrate schema theory in which the world is perceived through a framework of categories and relationships. Other cognitive approaches build on Fowler (1977) and Leech and Short's (1981) analysis while focusing on 
metaphors. This is mainly realized by integrating Conceptual Metaphor Theory developed by Lakoff and Johnson (1980). More recent approaches are interested in the process of cognitive reception of different mind-styles; for example, Semino (2002) attempts a mind-style analysis of narrative fiction incorporating Text World Theory.

It is clear that most cognitive approaches are either interested in depicting the mind-style of narrators and/or characters or of receivers. However, the current study is more interested in depicting the mind-style of authors. In particular, the study attempts to compare between T. S. Eliot (1888 - 1965) and Ahmed Shawqi's (1870 - 1932) mind-style depiction of the feline umwelt. Both Eliot and Shawqi are poet laureates; they are celebrated figures in English and Arabic poetry, respectively. In addition, both poets have written poems depicting the umwelt of cats. Accordingly, the study opts to adopt Leech and Short's (2007) approach to mind-style integrating poetic tools from Leech (1991) to examine Eliot and Shawqi's mind-style conceptualization of the feline umwelt.

\section{Data}

Eliot's Old Possums Book of Practical Cats is composed of 14 poems. As the title suggests, the poems introduce the practical lives of cats, especially the side people are unaware of. The book opens with "The Naming of Cats" in which the speaker argues that each cat has a name that is different from those given by humans. "The Old Gumbie Cat" explores a domestic cat's life at night. "Growltiger's Last Stand" takes the audience to a gangster-like world where Growltiger meets its doom. "The Rum Tum Tugger" is about a cat that is hard to please. "The Song of the Jellicles" introduces the Jellicle cats and how they prepare for the Jellicle balls. "Mungojerrie and Rumpelteazer" introduces two mischievous cats and the troubles they cause. "Old Deuteronomy" is about a famous retired old cat. "The Pekes and the Pollicles" is about trouble created by the peke and Pollicles dogs and the Rumpus cat's appearance that clears out the mess. "Mr. Mistoffelees" is about a clever, skillful magician cat. "Macavity: The Mystery Cat" is a master criminal that can break every law but is never held accountable. "Gus: The Theatre Cat" is an old cat that likes to reminisce about its old glorious days of being a theater actor. "Bustopher Jones: The Cat about Town" presents the habits of a well-respected overweight cat. "Skimbleshanks: The Railway Cat" proves that Skimbleshanks is the real master of the midnight train. Finally, "The Ad-dressing of Cats" recapitulates by saying that cats are like people and they deserve to be addressed with respect.

Shawqi’s الشوقيات (Alšsawqyāt) is a collection of all his poems. By scanning his anthology, it was found that poems about cats are mainly present in "الحكايات" (Allhekāyāt, The Stories) and "ديوان الأطفال" (Dywān Ālātfāl, Children's Anthology). In "الحكايات" (Älhekāyāt, The Stories), Shawqi has three poems about cats. It is assumed that the speaker in "ضيافة قطة "ضyāfat Qiṭah, A Cat's Hospitality) is Shawqi himself who narrates his encounter with a mother cat he finds in his room.

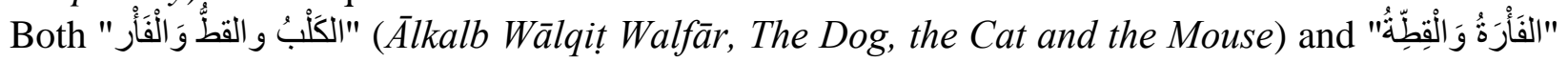
(Álfärah Walqitah, The Mouse and the Cat) take the reader to the feline umwelt as the poems present a backstage account of the cat-mouse relationship. In "ديوان الأطفال (Dywān Ālätfāl, Children's Anthology), Shawqi's "الْهرَّةُ و النَّظَافة" (Allherah Wālnazaâfah, The Cat and Cleanliness) celebrates the cat as a clean domestic pet. 


\section{Methodology}

In their analysis of William Faulkner's The Sound and the Fury, Leech and Short (2007) look at how the novel's general structure, the choice of lexis, the syntax and the textual relations capture the different mind-styles of the novel's four narrators. The structure of their analysis is based on their suggested model also present in Style in Fiction (2007). In their model, they introduce many tools that can be grouped under four main categories: "lexical categories, grammatical categories, figures of speech, and cohesion and context" (Leech \& Short, 2007, p.61). The current study adopts Leech and Short's (2007) model; however, only relevant tools are selected. It is believed that the chosen tools are more relevant to the poems in question, and are more applicable to both English and Arabic. The selected tools can be grouped under three main categories: (a) lexico-grammatical tools; (b) textual tools; (c) poetic devices. The first two sets offer a micro and macro view of the poets' mind-styles, respectively; the third category is mainly devoted to the poetic nature of the selected texts. Figure 1 groups the various tools under their respective categories.

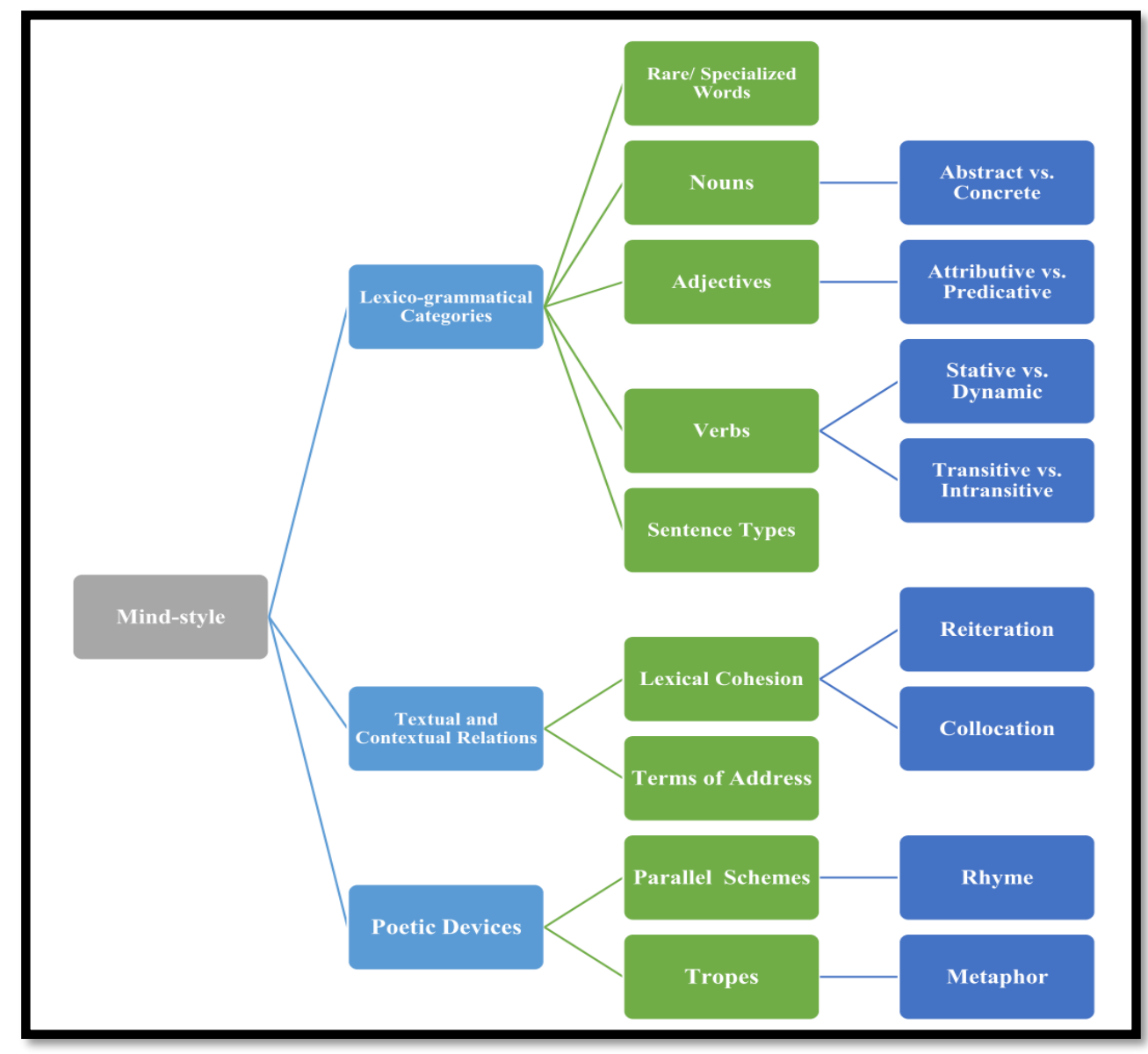

Figure 1

The Linguistic Tools Adopted in the Study 
In this study, an analysis of the lexico-grammatical tools looks at:

- evidence of rare or specialized words: The use of rare or a particular form of a word such as neologisms or a special compounding of morphemes may reveal much about how a writer views the world.

- abstract versus concrete nouns: Whereas concrete nouns refer to tangible entities that can be sensed, abstract nouns refer to events or processes that are conceptualized.

- attributive versus predicative adjectives: By modifying nouns, adjectives present a selective view of the world. As attributive adjectives associate nouns with certain sensory attributes that precede the noun, predictive adjectives tend to mark a statement after the noun is introduced.

- stative versus dynamic verbs: Dynamic verbs are associated with movement and action; accordingly, subjects associated with dynamic verbs are active. Stative verbs report states; this could reveal how characters are associated with more contemplative mental or habitual activities.

- transitive versus intransitive verbs: Transitivity, in this study, will be viewed in terms of agency and influence. Transitive verbs affect an object, unlike intransitive verbs which do not need an object.

- sentence types: Sentence types include questions, imperatives, exclamations and statements. The dominance or the frequency of each sentence type may reveal much about the writer's mind-style. The Arabic poems are further explored by distinguishing between verbal and nominal clauses of the declarative statements.

Leech and Short's (2007) explore textual and contextual relations by examining:

- cohesive devices: Halliday and Hassan (1976) present a seminal study of cohesive devises in English. In this study, the focus is on lexical cohesion that is achieved via lexical reiteration or collocations. "A reiterated item may be a repetition, a synonym or near-synonym, a superordinate, or a general word" (Halliday \& Hassan, 1976, p.278). Collocating lexical items achieve cohesion as they form some recognizable semantic relation.

- terms of address: In this study, terms of address are explored by looking at the relationship between the speakers of the poems and the readers on the one hand, and between the characters depicted in the poems, on the other.

Because the texts selected for the study are all poems, an analysis of the poetic devices is demanded. Accordingly, some of the tools introduced in Leech's (1991) A Linguistic Guide to English Poetry are borrowed. The tools can be seen as an instance of deviation away from the norm. Leech (1991) marks this stylistic deviation as a case of foregrounding, "which invokes the analogy of a figure seen against a background" (p.57).

Leech (1991) categorizes linguistic foregrounding into schemes and tropes; while the former highlights "foregrounded repetitions of expression", the latter stresses "foregrounded irregularities of content" (p. 74). In this study, parallel schemes are examined by looking at instances of rhyme, which result from the repetition of the final syllable. Leech's discussion of foregrounding tropes centers on irregularity that can be created because of the semantic redundancy or absurdity. In this study, figurative tropes, which are mainly absurd until interpreted 
figuratively, are explored. Leech (1991) argues that metaphors, built upon implicit comparisons between a TENOR (what is compared) and a VEHICLE (what is compared to), epitomize the process of transformation of meaning; accordingly, the use of metaphors is examined.

\section{Analysis}

Both Eliot and Shawqi take their audience to the feline umwelt. While both poets situate some of their poems in the human umwelt, the speakers offer a feline perspective of this world. In addition, both poets introduce a behind-the-scene account of the feline umwelt. Accordingly, the study aims at tracing regular linguistic patterns in Eliot's and Shawqi's poems about cats in attempt to project the poets' mind-style visualizations of the feline umwelt.

\subsection{Lexico-grammatical Patterns}

\section{- Rare or Specialized Words}

Eliot introduces his readers to the feline protagonists of his poems using neologistic names that are either coined or compounded. Names signify identity, and by coining new names, Eliot is inviting his audience to meet new cats with new identities. Eliot employs compounding to produce names like "Jennyanydots", "Growltiger", "Griddlebone", "Tumblebrutus" and "Skimbleshanks". He also coins new names such as "Rum Tum Tiger", Jellicle”, Mungojerrie", "Rumpelteazer", "Rumpuscat", "Mistoffelees" and "Bustopher". Interestingly, Eliot also clips some of the names to produce "Gus" from "Asparagus" and "Skimble" from "Skimbleshanks".

In addition, Eliot forms new words to account for specialized meanings. For instance, to describe the names cats keep for themselves, Eliot combines "Effanineffable" from "effable" and "ineffable". "Fireforfiddle" is another compound that refers to Gus" "grandest creation". In addition, Eliot converts the phrasal verb 'pull away' into the noun 'pullaways' which could hint at the slightly different means of transportation associated with cats. Derivation is employed in "destroyment", which could have been coined to maintain the rhyming pattern of the poem or to refer to a different kind of destruction, only perceived by the cat. In his final poem of the anthology, Eliot uses the word "ad-dressing", which can be seen as the derived noun from the verb 'address' and/or the compounding of 'ad' and 'dress'. It can be argued that ambiguity here is intended, for addressing a cat means also giving it a dress, which is a human trait.

Furthermore, words like "skeered" and "gawn" could be seen as spelling alternatives to 'scared' and 'gone', respectively. The new spelling suggests different shades of meaning; for example, a scared cat is different from the kind of fear a human understands. Similarly, 'gawn' accounts for the mysterious ways of Mr. Mistoffelees' disappearance. Eliot also employs the alliterating "ker-flip, ker-flop" and the rhyming "huffery-snuffery" phrases to refer to feline acts and places, respectively, which are not really known outside the feline umwelt.

On the other hand, Shawqi does not employ any rare or specialized lexical items. The absence of newly compound or coined words can be interpreted as Shawqi's attempt to translate the feline umwelt into a world that is understood by his audience. It can be also argued that Shawqi's visualization of the feline umwelt is bound by the tools offered in the human umwelt; Shawqi imagines the world of cats as a world similar to that of the human's. Accordingly, Shawqi 
does not employ new terms to account for a new or a different umwelt. This is to be contrasted with Eliot who opts for new words that evoke the audience's imagination and invites them to visualize a new world that does not correspond to the human umwelt.

\section{- Abstract versus Concrete Nouns}

Eliot's pattern of employing abstract and concrete nouns reveals much about his conceptualization of the feline umwelt. In his 14-poem anthology, seven poems are dominated by concrete nouns while the other seven enjoy an approximate equilibrium as concrete and abstract noun share similar frequencies. The ratio means that concrete nouns outweigh abstract ones, which could explain how Eliot's reproduction of the feline umwelt relies on nouns that appeal to the readers' senses.

In "The Old Gumbie Cat", concrete nouns are associated with the cat's looks ("coat", "tiger stripe" and "leopard spots"), where it goes ("basement", "mat", "hearth" and "windowsill") and the results of its actions ("music, crocheting and tatting"). On the other hand, abstract nouns are associated with the cat's "work" and "manner". Similarly, in "The Song of the Jellicles", concrete nouns are used to describe the unknown "Jellicle" world of balls and festivities. Accordingly, the few abstract nouns, such as "airs", "graces" and "powers", are explained by the concrete nouns that describe the cats" "faces", "eyes", "ears" and "toes". In a parallel vein, Eliot compares Mungojerrie and Rumpelteazer to "clowns", "comedians", "tight-rope walkers" and "acrobats". These concrete nouns explain the abstract nouns denoting the cats' "reputation", "gift[s]", and "luck".

Because "Old Deuteronomy" is a celebrity, the poem relies on concrete nouns that describe how "inhabitants" and "villagers" react to Old Deuteronomy's fame. However, the nouns associated with the cat are mostly abstract nouns: "chance", "rest", "trouble", "sleep", and "decline". In "The Pekes and the Pollicles", all the nouns associated with Rumpuscat are concrete, as they refer to its "eyes", "glare" and "jaws. "Bustopher Jones" is dominated by concrete nouns describing the cat, the places it frequents and the types of food it likes. The few abstract nouns refer to its "visits", "routines" and "weight". As for the "The Rum Tum Tugger", the prevalent concrete nouns account for the items the speaker offers the cat hoping to please it, such as "pheasants", "house", "mouse" and "cuddle", and the items desired by the Rum Tum Tugger, such as "grouse", "flat", "rat" and "sewing". Abstract nouns refer to the cat's state, which needs some effort to grasp, for the cat's "ways", "matters", and "habit" are not so easy to perceive.

Whereas concrete nouns dominate some poems to help readers visualize the abstract feline umwelt, others can be said to have a proportional distribution of abstract and concrete nouns. In the opening and the closing poems of the anthology, concrete nouns are associated with how cats are perceived in the human umwelt, and abstract nouns signal the feline umwelt. For example, in "The Naming of Cats" concrete nouns such as "cat", "tail", and "whiskers" describe the cats perceived in the human world. In contrast, abstract nouns, such as "name", "meditation", "contemplation", and "thought", report accounts that are not perceivable to man.

"Growltiger's Last Stand" takes the readers to a parallel feline umwelt, which occupies the same space of the human umwelt, so the setting is created by concrete nouns. Growltiger, his 
crew and his enemy are also referred to using concrete nouns. However, abstract nouns, such as "manners", "appearance", "hatred", "fear", "attention", "surprise", and "relaxation", account for the feline umwelt that can only be perceived through imagination.

In "Mr. Mistoffelees", abstract nouns inspire readers to think of the magical world created by Mr. Mistoffelees' “inventions”, “illusions", “confusions”, "prestidigitation”, "legerdemain”, "conjuring", "trick" and power". Concrete nouns exhibit the tools used by the cat to create its magic, such as "hat", "cork", "knife", "fork". Similarly, concrete nouns in "Macavity, the Mystery Cat" refer to the cat as a "criminal", mention the places it loots, compares it to a "snake", and account for the stolen "larder" and "jewelry". However, the abstract nouns depict the "bafflement" Macavity causes by being a "master" of "crime" and speak of its "deceitfulness" and "suavity".

In "Gus, the Theatre Cat", concrete nouns refer to Gus' current appearance ("coat", "rake", "paw", "claws", and "tail") and the places it frequents ("theatre door", "club" and "pub"). Abstract nouns refer to its past, the prime time of success. Through "anecdotes", Gus tells of the "days", "degree" of "success", "rehearsal[s]", "history" and "performance[s]". In a parallel vein, concrete nouns in "Skimbleshanks, the Railway Cat" present the world of the "Midnight Train" whereas abstract nouns present how Skimbleshanks maintains order on the train: "charge", "control" and "patrol".

"ضيافة قطة" Similarly, most of the nouns used in Shawqi’s poems are concrete nouns. In

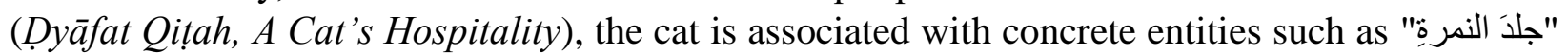

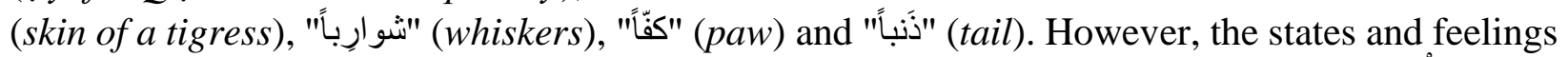

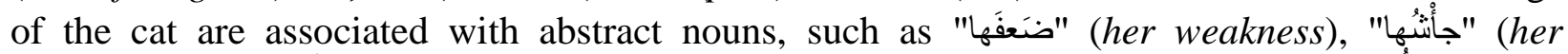

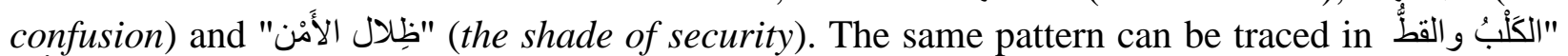
" (َ) الْفَاْر" (Alkalb Wālqiț Walfār, The Dog, the Cat and the Mouse). For example, concrete nouns place

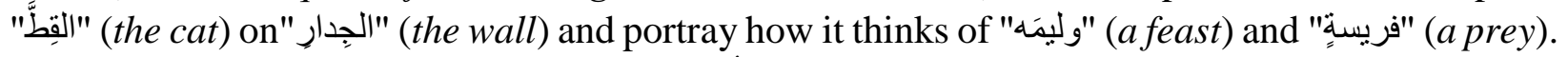

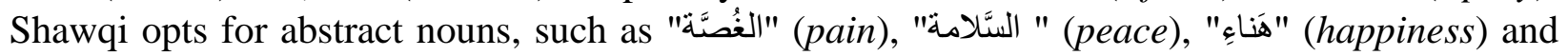
"إحسانا" (charity), to account for the cat's pain, happiness and magnanimity.

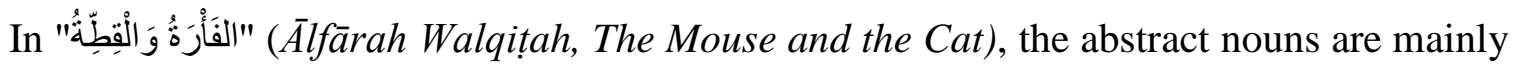
associated with the mouse that commiserates the death of a nephew; however, since this death is brought about by the cat, the abstract nouns reflect states associated with feline umwelt. Abstract

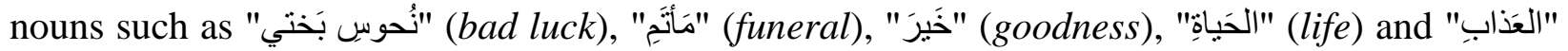
(suffering) are to be compared to the cat's ironic words "بُشر الكِكَ" (congratulations). On the other hand, Shawqi employs concrete nouns to present the dramatic scene performed by the cat and

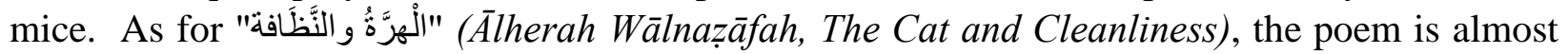
free of abstract nouns; concrete nouns presenting the cat's setting within the speaker's house prevail.

\section{- Attributive versus Predicative Adjectives}

Eliot mainly devotes attributive adjectives to claims and views that may differ for one reason or another; predicative adjectives, on the other hand, are used to make a statement and present facts allowing no scope for disagreement. It is interesting to note that both the opening and final poems of the anthology have proportional shares of attributive and predicative adjectives. In 
"The Naming of Cats" attributive adjectives are associated with the "sensible" or "fancier" names given to cats by their owners whereas predicative adjectives represent the speaker's views of cat names as "peculiar" and "dignified". The speaker yet resorts to attributive adjectives to describe the cat's "ineffable", "effable" names since it is very difficult to understand a cat's name from a feline perspective. As for "The Ad-Dressing of Cats", predicative adjectives recapitulate the poem speakers" views about cats, for they could be "sane" or "mad" or "good" or "bad" just like humans. Attributive adjectives refer to the cat's behavior; it depends on a cat's "personal taste" to treat a human as a "trusted friend" or not. Thus, in this poem, predicative adjectives still present fact-like views of the feline identity, but attributive adjectives no longer have to do with how humans see cats, but with how cats see humans.

Attributive and predicative adjectives are employed equally in "The Old Gumbie Cat", "The Song of the Jellicles", "The Pekes and Pollicles" and "Mr. Mistoffelees". In "The Old Gumbie Cat", attributive adjectives are associated with the cat's morning activities and the "warm" and "sunny" spots it prefers. At night, as the cat sets about its real work, predicative adjectives show how it is "concerned" about the mice. In "The Song of the Jellicles", attributive adjectives describe cats as having "cheerful faces", "bright black eyes" and "moderate size". Predicative adjectives emphasize these descriptions by showing, for example, that the Jellicle cats are "rather small" and "not too big". In "The Pekes and the Pollicles", attributive adjectives build a contrast between the "bold" dogs, and the "GREAT RUMPUSCAT" that walks out of a "small basement flat". Predicative adjectives also build contrasting images between the people who are "afraid" of the chaotic scene created by the dogs and the impression of a "blazing", "amazing" and "fiercer" Rumpuscat. In "Mr. Mistoffelees", attributive adjectives are associated with the "surprising", "eccentric", "greatest", "magical" and "phenomenal" "Original Conjuring Cat" while predicative adjectives present Mr. Mistoffelees' skills as undisputed facts; the cat is "clever", "cunning" and "vague".

Attributive adjectives are dominant in the rest of the poems. Because "Growltiger's Last Stand" is about a cat's journey from glory to demise, attributive adjectives are used to reflect the changeable state. At first, Growltiger is seen as the "roughest" cat with "evil" aims and "forbidding" eyes. However, as the "ruthless foe" approaches, Growltiger sings its "last duet" and his crew become "hundred victims". Predicative adjectives are barely employed in this poem. In "The Rum Tum Tugger" attributive adjectives dominate to account for the "curious", "terrible", "horrible" cat with its "disobliging" ways. Despite this view, Eliot's use of predicative adjectives asserts that the Rum Tum Tugger is an "artful", "knowing" cat hinting at the human's inability to interpret its needs. Attributive adjectives describe cats as "notorious", "horrible", with "knockabout" skills, "extensive" reputation and a "wonderful" spirit of cooperation in "Mungojerrie and Rumpelteazer". The limited use of predicate adjectives is reserved to the evidence of the cats' mischief, for they are the reason why the window is left "ajar" and the rooftop ceases to be "waterproof".

In "Old Deuteronomy" attributive adjectives are frequently used to convey how villagers talk about the "famous", "old" cat with the "placid and bland physiognomy". Predicative adjectives present facts about the cat's state of being "proud" and "disposed" when "engaged" in matters of 
"domestic economy". "Gus, the Theatre Cat" is another celebrity, but it is more of a has-been. Attributive adjectives, such as "highest" are "grandest", are employed in Gus' nostalgic report of the days of glory. In contrast, predicative adjectives present the current realistic view of the "shabby", "thin" and "famous" cat, not denying the fact that it is "the smartest" of cats.

Predicative adjectives dominate "Macavity, the Mystery Cat", "Bustopher Jones, the Cat about Town" and "Skimbleshanks, the Railway Cat". It is important to note that these poems are located in the second half of the anthology, which means that as Eliot's depiction of the feline umwelt progresses through the poems, statements about cats become more frequent. Predicative adjectives dominate "Macavity, the Mystery Cat" to account for reports about the cat's physical appearance, which is the only known fact about it. However, the few attributive adjectives explain the mysterious side of the cat, known as the "Hidden Paw" that might be engaged in "complicated long division sums". Predicative adjectives in "Bustopher Jones, the Cat about Town" describe the "fat" cat that continues to gain weight. The few attributive adjectives modify the "impeccable" taste of food and the description of places frequented by Bustopher. As for "Skimbleshanks, the Railway Cat", predicative adjectives accentuate the control exercised by the cat on the train; the cat is "nimble" as it stays "busy" to keep everyone "quiet" and satisfied.

The choice of adjectives also sheds light on Shawqi's mind-style depiction of cats. It has to be noted that Shawqi's use of adjectives is very minimal in comparison to nouns and verbs. Shawqi relies on predicative adjectives more, which means that he sends his description as statement of facts. For example, in "ضيافة قطة" (Dyâfat Qițah, A Cat's Hospitality), the predicative "كالجَبان" (كالعُمْىى" (as a coward) and (as blind ones) are used to describe the cat's

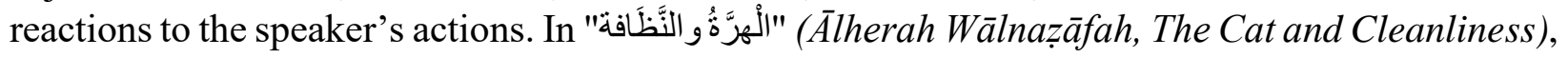
Shawqi modifies the cat with predicative adjectives that confirm why the cat is a popular pet in Egyptian households. It is "ظُخريفة" (funny); it continuously recites prayers that are "شريفه" (holy), and it is clean as it washes itself using methods that are "طنيفه" (nice). The only attributive adjective is used to modify the cat's fur (dress): "حسَنَ الثوبِ (good dress), which again denotes the speaker's appraisal of the cleanliness of the cat.

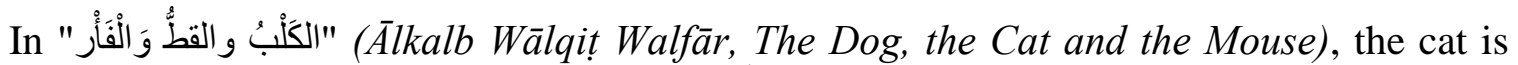
associated with only one attributive adjective "أَضَيَتِّ (narrowest) that modifies the dog's trap. In return, the predicate adjectives "على بِدار (ready) and "مبتهجاً" (happy) depict the cat's hurry to escape the trap and its happiness and readiness to celebrate the victory. Juxtaposing the attributive and predicative adjectives highlights the power relationship between the cat and the dog, which explains how the feline ecosystem functions. The power hierarchy between the cat and the mouse

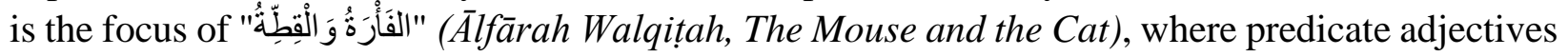
describe the cat as "سَفيهِه" (foolish) and the suffering it causes the mice as "المرِِّ" (bitter).

\section{- Verbs (Stative versus Dynamic and Transitive versus Intransitive)}

Eliot's pattern of using stative and dynamic verbs as well as transitive and intransitive verbs presents a clear vision of how he visualizes the feline umwelt from a human and a cat perspective. In most poems, dynamic and transitive verbs are more frequent. This explains how Eliot sees cats as active and influential agents. Verbs associated with "The Old Gumbie Cat" are mostly dynamic 
transitive verbs, such as "teaches", "makes", "prevent", "formed" and "created". These verbs sketch the dynamic role the cat plays "when all the family's in bed" (L.7). This is to be contrasted with the dynamic intransitive verb "sit" that is repeated 15 times; intransitivity here exhibits how the family interprets Gumbie's ineffective role in the house. Stative verbs like "to be", "to have", "creeps", "likes" and "thinks" highlight the state of the cat that is mostly ignored by the family.

"The Rum Tum Tugger" and "Mr. Mistoffelees" are also dominated by dynamic transitive verbs that showcase that cats' active roles that transcend the feline umwelt impacting the human umwelt. For example, the "Rum Tum Tugger" rejects what it is offered to "chase", "make", "eat", "sniff" and "find" on its own. Intransitive dynamic verbs, such as "lies", "gets out" and "sneer", present how the cat has a say in deciding its course of life. Stative verbs explain the cat's attitude and what it "wants", "likes" and "enjoys". Similarly, the clever Mr. Mistoffelees can "defy", "deceive", "pick", "hunt", "play and trick" and "produce". In contrast, dynamic intransitive verbs depict how the cat is seen as it 'walks', 'creeps through' and 'curls up'.

In a parallel vein, "Macavity, the Mystery Cat" and "Gus, the Theatre Cat" are mostly associated with dynamic transitive verbs that denote their impact in the world of crime and theater, respectively. Macavity 'defies', 'breaks', 'steals', 'loots' and 'rifles' while Gus 'joins', 'regales', 'tells', 'plays', 'extemporizes', 'understudies', ‘crosses', 'rescues' and 'scratches'. It is important to note here that in "Gus, the Theatre Cat", stative verbs refer to its current old state where stative transitive verbs like "likes", "loves" and "knows" prove that Gus' existence is still influential.

The events of "Growltiger's Last Stand", "The Song of the Jellicles" and "Bustopher Jones, the Cat about Town" take place in the feline umwelt. Accordingly, dynamic intransitive verbs dominate as cats assume active roles that do not really influence the human umwelt. For example, cats in "Growltiger's Last Stand" 'roam', 'go', 'steal away', and 'swarm'. Similarly, the Jellicle cats "come", "jump", "dance" in the Jellicle balls. In addition, Bustopher Jones "walks" and "drops in" restaurants, so it "has grown" and continues to gain weight.

On the other hand, stative verbs dominate "The Naming of Cats", "Mungojerrie and Rumpelteazer" and "The Pekes and the Pollicles". In these poems, while the human umwelt and the feline umwelt intersect, the former fails to acknowledge the latter. To illustrate, in "The Naming of Cats", Eliot argues that cats 'need' names that 'belong' only to them, a name they 'know' and can 'cherish'; however, most people are ignorant of this need, so they give cat common or fancy names depending on their taste. "Mungojerrie and Rumpelteazer" are mainly associated with the stative intransitive verbs 'to be' and 'to have'; they "were a very notorious couple", "had extensive reputation", "were highly efficient cat-burglars" and "had no regular occupation". As for "The Pekes and the Pollicles", the dynamic intransitive verb "stalks out" is all the activity needed by the Rumpus cat to clear the mess created by the dogs. Stative verbs ensue, for example verb 'to be' is repeated to describe the impressive appearance of the Rumpus cat.

In "Old Deuteronomy", "Skimbleshanks, the Railway Cat" and "The Ad-Dressing of Cats" people are aware of the active roles of cats; accordingly, transitive, intransitive, stative and dynamic verbs are frequently employed. The stative intransitive verbs "to be", "live" and "feels" present the way Old Deuteronomy leads its life. In addition, the stative intransitive verbs "prosper" 
and "thrive" display the kind of life enjoyed by Deuteronomy's offspring. Dynamic transitive verbs, such as "buried", show the active role Deuteronomy played in the past; this is to be contrasted with the dynamic intransitive verbs "lies" and "sits" that shape his present.

In the penultimate poem of the anthology, Skimbleshanks also plays an important role; "the Night Mail just can't go" if Skimbleshanks does not show up (L.8). Dynamic transitive verbs, such as "hunt", "gives", "supervise", "examines", "establishes", "let" and "help", picture the kind of role Skimbleshanks plays on the train. Nevertheless, dynamic intransitive verbs complete the picture as Skimbleshanks "appear[s]", "saunter[s]", 'walks' and "speaks". Stative verbs, such as "know", "sees", "approve" and "is keeping", shed light on the kind of leader Skimbleshanks is.

In "The Ad-Dressing of Cats", the poem begins with stative verbs such as the intransitive "are" and "have" and continues with the transitive verbs "resents" and "treats" to express the state of cats whose feline umwelt existence is not yet acknowledged. However, as the speaker attempts to befriend the cat and to address it the way it should be, dynamic transitive verbs, such as "makes", "finished", "licks" and "wastes", are evident. Thus, the use of verbs does not only express Eliot's views of the feline umwelt, but his perspective of how the feline umwelt is and should be perceived within the human umwelt.

In Shawqi's poems, verbs indicate the cat's active/inactive roles as they are compared to

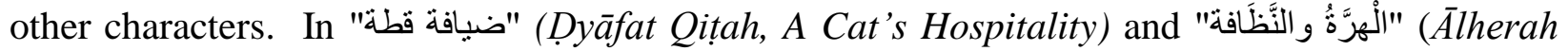
Wālnazāfah, The Cat and Cleanliness), the cat's agency and influence can be seen in the light of

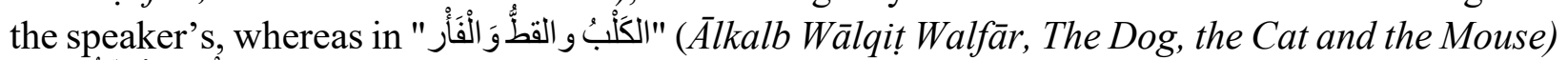

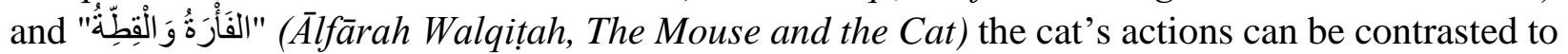
those of the mouse. To illustrate, in "ضيافة قطة (Dyāfat Qitah, A Cat's Hospitality), the cat is

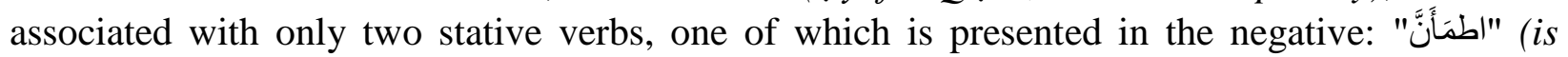
reassured) and "ما دَرَتْْ (did not know). In contrast, the speaker is associated with the rest of the

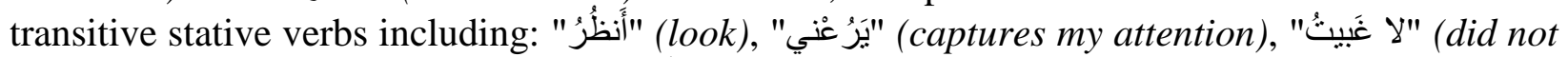

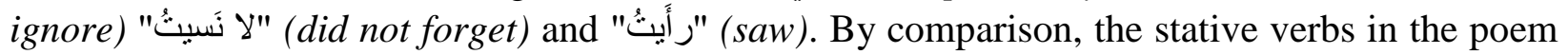
seem to extend to their doer some sort of cognitive abilities. On the other hand, dynamic verbs are associated with both the speaker and the cat. However, the cat's dynamic verbs are a reaction to

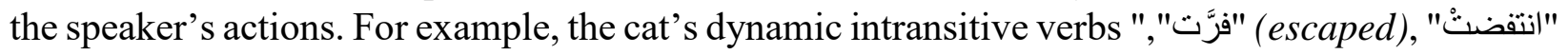
(frightenedly rose), "هَوَتُرَّتَ" (howled) and prove that the cat's influence does not really

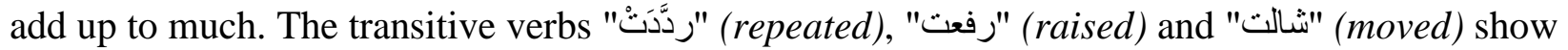
the limited influence over the cat's body, for it can only use its voice, hands and tail, but as the poem shows to no avail. Moreover, as the speaker attempts to gain the cat's trust, he engages in

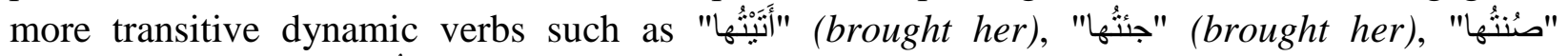
(protected her) and "'زَنْنُها" (supplied her). In response, the cat and her kittens perform further intransitive dynamic actions that reflect their sense of security, such as "اضطجَتَّت (laid down),

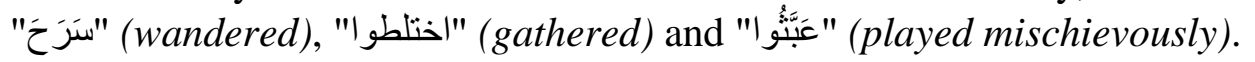

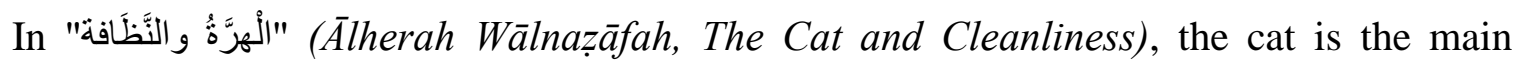
character of the poem and almost all the verbs are associated with its actions. While two of these

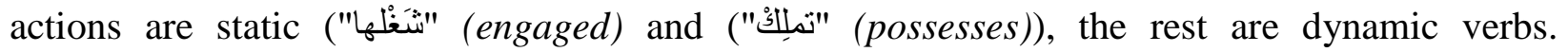

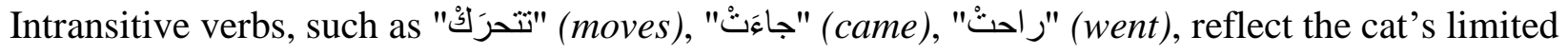




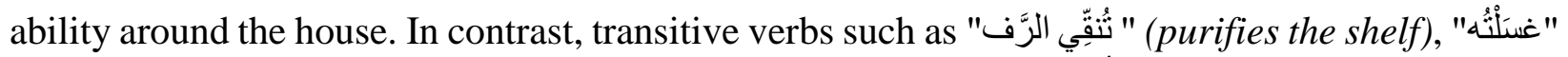

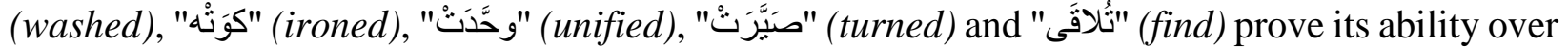
the mice and over its body parts.

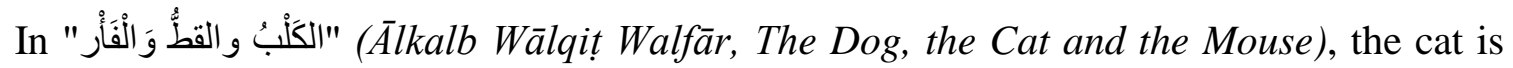
only associated with the stative intransitive verb "يفكر" (thinks); instead, all the dynamic transitive verbs sketch a scene in which the cat is a powerful active being, for the cat "يجعلها" (writes), (makes it) and "يأكنُ" (eats it). The feline umwelt can thus be seen as one where the cat is capable of uninfluential mental actions, but effective and powerful dynamic ones. This pattern of verb

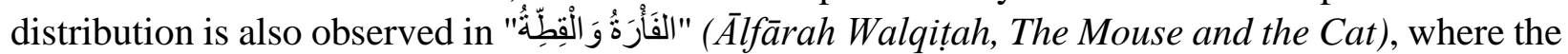
cat is associated with one stative transitive verb, "يَسَسَعْعَ" (hears), which depicts the cat as a schemer that eavesdrops on the mice. The dynamic transitive verbs also reflect the influence the cat has over the mice as it is able to "يُريح" (relieves) the mice from their misery. Furthermore, the influence of the cat appears in the absence of intransitives in association with the cat, as all

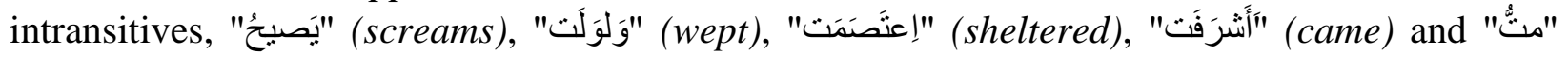
(died), are reserved to the mouse.

\section{- Sentence Types}

Eliot mainly relies on declarative statements to convey his conceptualization of the feline umwelt. In the 14 poems, the speaker introduces the audience to different cats, their traits, their life-style, how they are perceived and how they act. However, in 8 poems, exclamations are frequently used. They are first introduced in the second poem of the anthology "The Old Gumbie Cat"; the repeated exclamative "and that's what makes a Gumbie Cat!" draws the reader's attention to the new perspective of the feline umwelt. The exclamation "And there's no doing anything about it!" in "The Rum Tum Tugger" signals man's helplessness to understand the cat and its preferences. In "Mungojerrie and Rumpelteazer", exclamations convey people's reactions to the notorious couple: "II's that horrible cat!". In a similar way, exclamations in "Macavity, the Mystery Cat" communicate the sense of bewilderment created by Macavity, "the Napoleon of Crime!", especially as it flees the scene causing the repeated exclamative reaction, "Macavity's not there!".

Exclamations in "Old Deuteronomy" are also used to express people's reactions to the famous cat. The lines "Things. . . Can it be . . . really! . . No!. . . Yes!. . ./ Ho! hi!/ Oh, my eye!" prove the star-like status of the cat. Similar reactions are noticed in "Mr. Mistoffelees" where people are awe-stricken by the magical skills of the "Original Conjuring Cat" (L.2). Another wellknown cat is "Bustopher Jones"; exclamations mirror paparazzi news that follows the cat. In addition, the exclamative "And we're all of us proud to be nodded or bowed to/ By Bustopher Jones in white spats!" reveals the cat's formidable reputation.

Exclamations perform other functions in the poems. In "Skimbleshanks the Railway Cat", exclamations act as signals of tone change. For example, as soon as the mystery behind Skimbleshanks is solved, a sigh of relief is observed in "He's been busy in the luggage van!". In addition, a more energetic tone can be heard as the train gets ready to leave, hence the exclamative "All Clear!". Finally, a tone of satisfaction is implied as customers are seen off by Skimbleshanks, 
"For Skimbleshanks will help you to get out!". In "The Ad-Dressing of Cats", exclamations are used to evoke a vocative case in "O CAT!" or "OOPSA CAT!".

Interrogatives also invade the declarative statements in 5 poems. In "The Naming of Cats", the speaker wonders "Else how can he keep up his tail perpendicular/ Or spread out his whiskers, or cherish his pride?". The rhetorical question is directed to the audience inviting them to raise questions about a cat's feelings. Similar rhetorical questions are evident in "The Ad-Dressing of Cats" where the speaker asks the audience "How would you ad-dress a Cat?" inviting their involvement before providing the answer, "And there's how you AD-DRESS A CAT." (L.69).

In "Mungojerrie and Rumpelteazer", questions convey the sense of confusion created by the two cats. Questions like "Was it Mungojerrie--or Rumpelteazer? or could you have sworn that it mightn't be both?" illustrate how people can easily confuse two similar cats. In comparison, questions in "Mr. Mistoffelees" relay a sense of astonishment realized in the interrogative "Was there ever/ A Cat so clever/ As Magical Mr. Mistoffelees!". Despite the exclamation point at the end, the lines are structured like a question, for Mr. Mistoffelees challenges traditional beliefs associated with cats.

In "Skimbleshanks, the Railway Cat", questions are used to inquire about Skimbleshanks' whereabouts, highlighting the important role Skimbleshanks plays on the train. Furthermore, under Skimbleshanks' supervision, the guards ask passengers questions like "Do you like your morning tea weak or strong?". The question here is an indication of the top service provided on the train.

Imperatives are rarely traced in the poems; nevertheless, they are of significance. While speaking of Mr. Mistoffelees, the speaker asks his audience to "listen" and not to "scoff". It is important to note here that the use of imperatives is preceded by "Please", which denies the power relationship suggested by the imperative structure. The imperatives in "Mr. Mistoffelees" are more of demands than commands; they are put forward because the speaker knows that it might be hard for his audience to believe the incredulous accounts of Mr. Mistoffelees and its magical umwelt. As for the imperatives in "The Ad-Dressing of Cats", they are, in fact, a direct report of common instructions on how to deal with cats. The speaker argues against rules such as "Don't speak till you are spoken to", for he believes that cats should be addressed.

In a similar vein, Shawqi’s poems are dominated by declarative statements. In "ضيافة قطة (Dyāfat Qitah, A Cat's Hospitality), verbal clauses are dominant because the poem can be seen as an encounter between the speaker and the cat. Only three instances of nominal clauses are traced:

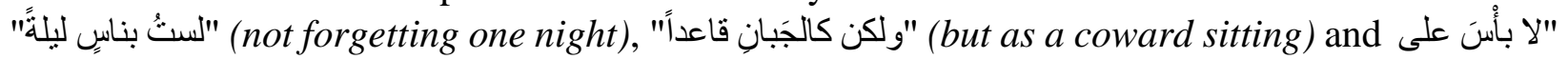
طفِلlin (no worries about your child). The use of nominal phrases can be seen as a grammatical necessity since they are presented as a commentary to verbal phrases and they are preceded by markers ("لكن" (" لكن" (not), "لات" (no)) that are only inserted in nominal clauses. There is also one instance of imperative sentence in which the speaker addresses the cat, "نََخَّضي عن خمسةٍ " give birth to five). The use of the imperative highlights the power of the speaker over the cat.

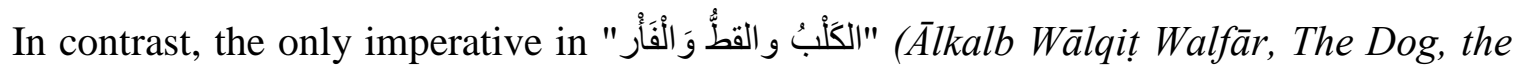
Cat and the Mouse) proves the cat's power as the mouse beseeches: "فامنُنْ بـ لِمعشَري إحسانانا" (charitably, bestow it upon own community). The rest of the sentences are declarative statements. 
Most of them are verbal clauses accounting for the actions of the cat, the reactions of the mouse

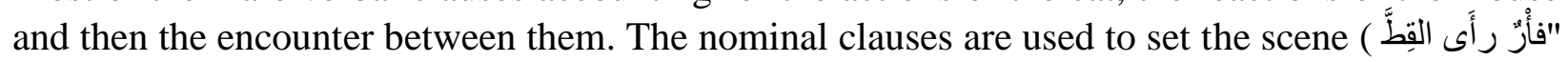
(a mouse saw the cat on the wall) and "ولى الجِدارِ" (the dog in its usual state))

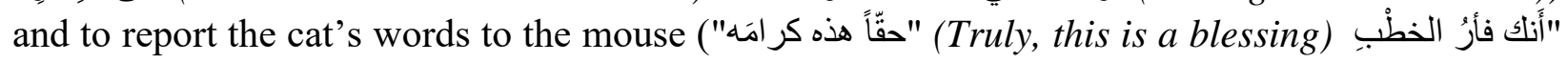
(you're the mouse of speeches and feasts)).

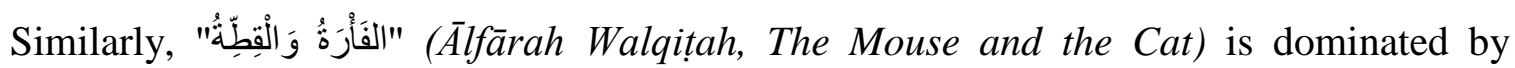
declarative statements; verbal clauses outweigh nominal ones. The verbal clauses document the actions of the mouse, the arrival of the cat and the mouse's attempt to escape its fate. The nominal clauses are those marked by "إن"ا", "كان", which means that the nominal clauses are there to serve grammatical functions. There are also three instances of interrogative sentences; they are all questions raised by the mouse: "مَن سَلَّط القِطًَ عَلى إبنِ أختني" (Who let the cat loose on my nephew?),

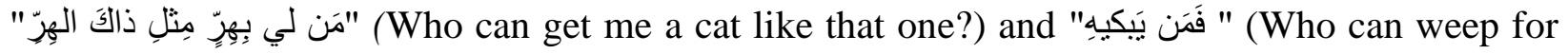
him?). Both the first and the second questions hint at a tone of defiance; however, the third question brings the mouse to reality as it reasons with the cat by wondering who would lament the dead son if it is killed. Thus, while the questions are mainly associated with the mouse, they reflect the feline influence within its realm.

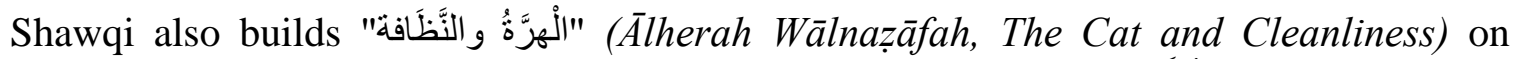

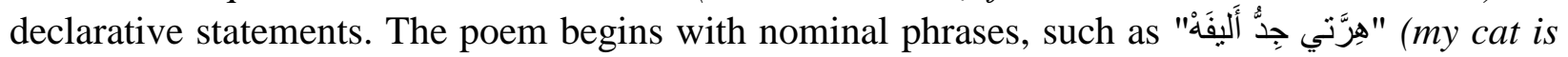

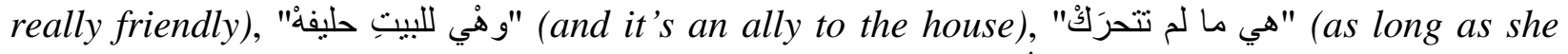

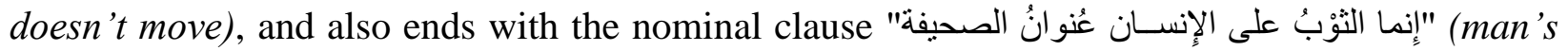
attire is like a book's cover). The opening nominal clauses introduce the cat's status in the house; the choice of nominal clauses here accent that the matter-of-fact role of the cat as a pet. As for the rest of the poem, verbal clauses are used to account for the cat's movements around the house, its attempts to get rid of mice and fleas and its actions to clean herself.

\subsection{Textual and Contextual Relations}

\section{- Lexical Cohesion}

Eliot makes use of reiteration and collocations to tie the lines of the poems and present each as one unit. In fact, in 9 out of the 14 poems, Eliot uses some lines as refrains that run throughout the poem, either verbatim or with some modifications. These refrains connect each group of lines and/or verses to the topic in focus. For example, in "The Old Gumbie Cat", the initial line, "I have a Gumbie Cat in mind, her name is Jennyanydots;", is repeated in 3 stanzas. In the other 3 stanzas, the lines "“"But when the day's hustle and bustle is done,/ Then the Gumbie Cat's work is but hardly begun" and "“"All day she sits ...,/ She sits and sits and sits and sits - and that's what makes a Gumbie Cat!" are repeated. This summarizes the speaker's report and stresses that while the cat is seen in daylight doing something, its real work begins at night. Similarly, in "The Rum Tum Tugger", the refrain, "For he will do/ As he do do/ And there's no doing anything about it!", sums up the poem; it assures that the cat will eventually do as it pleases no matter what it is offered. Also, in "Macavity, the Mystery Cat", the line, "Macavity's not there!" recapitulates why Macavity is a mystery cat. Because "Bustopher Jones, the Cat about Town" centers around 
the cat's appearances and how it is treated despite its weight issue, the line "Bustopher Jones in white spats!" verifies the esteemed status the cat enjoys.

Refrains also highlight how people respond to cats, and how their reaction shapes up the role of the cat. For example, in "Mungojerrie and Rumpelteazer", the refrain, "Then the family would say: 'It's that horrible cat!/ It was Mungojerrie--or Rumpelteazer!'-- And most of the time/ they left it at that.", reiterates the cat's "notorious" reputation that is the focus of the poem. In "Old Deuteronomy" and "Mr. Mistoffelees", the repeated refrains attest the celebrity status of Deuteronomy and the extraordinary skills of Mr. Mistoffelees.

In "The Pekes and the Pollicles", the refrain, "Until you can hear them all over the Park." appears only till the Rumpus cat makes an appearance, which illustrates the impact of the cat and how it easily sorts out the mess created by the dogs. In "Skimbleshanks, the Railway Train", the refrain "The Cat of the Railway Train." runs in the second half of the poem mirroring the indispensable role Skimbleshanks plays.

As for reiteration and collocation, Table 1 presents examples that show how lexical cohesion connect the lines of each poem to its central topic.

Table 1

Examples of Lexical Cohesion in Eliot's Poems

\begin{tabular}{|c|c|c|c|}
\hline Poem & Reiteration & Collocation & The Poem Focus \\
\hline $\begin{array}{c}\text { "The Naming of } \\
\text { Cats" }\end{array}$ & $\begin{array}{l}\text { - } \quad \text { cat } \\
\text { - } \quad \text { names / } \\
\text { naming } \\
\text { - I tell you } \\
\text { - } \quad \text { thought }\end{array}$ & $\begin{array}{l}\text { - cat - tail/ } \\
\text { whiskers } \\
\text { - research - } \\
\text { discover } \\
\text { - ineffable - } \\
\text { effable }\end{array}$ & $\begin{array}{l}\text { Cats have names that } \\
\text { are different from } \\
\text { those people give } \\
\text { them. Names denote } \\
\text { cats' identities. }\end{array}$ \\
\hline $\begin{array}{c}\text { "The Old Gumbie } \\
\text { Cat" }\end{array}$ & $\begin{array}{ll}\text { - } & \text { cat } \\
\text { - } & \text { sits } \\
\text { - } & \text { makes }\end{array}$ & $\begin{array}{l}\text { - cat- mice } \\
\text { - cat - warm and } \\
\text { sunny spots }\end{array}$ & $\begin{array}{l}\text { Cats lead a different } \\
\text { kind of life that begins } \\
\text { at night. They are not } \\
\text { the lazy beings they } \\
\text { are known to be. }\end{array}$ \\
\hline $\begin{array}{l}\text { "Growltiger's } \\
\text { Tiger Stand"' }\end{array}$ & $\begin{array}{ll}\text { - } & \text { cat } \\
\text { - } & \text { eye } \\
\text { - } & \text { ear } \\
\text { - } & \text { was forced }\end{array}$ & $\begin{array}{l}\text { - } \text { prowling - } \\
\text { prey } \\
\text { - } \quad \text { sang - duet } \\
\text { - } \text { forks - knives } \\
\text { - } \quad \text { cats - rats } \\
\end{array}$ & $\begin{array}{l}\text { The glorious } \\
\text { Growltiger is finally } \\
\text { defeated. }\end{array}$ \\
\hline $\begin{array}{c}\text { "The Rum Tum } \\
\text { Tugger" }\end{array}$ & $\begin{array}{l}\text { - curious cat } \\
\text { - he'd/ would } \\
\text { rather } \\
\text { - offer/ put/ set } \\
\text { him on } \\
\text { - prefers/ wants/ } \\
\text { likes/ enjoys }\end{array}$ & $\begin{array}{l}\text { - } \text { house - flat } \\
\text { - } \text { mouse - rat } \\
\text { - in - out } \\
\text { - bureau - } \\
\text { drawer } \\
\text { - cat - fish }\end{array}$ & $\begin{array}{l}\text { The cat is difficult to } \\
\text { please. No matter } \\
\text { what one does, it will } \\
\text { always go about its } \\
\text { own ways. }\end{array}$ \\
\hline
\end{tabular}




\begin{tabular}{|c|c|c|c|}
\hline $\begin{array}{l}\text { "The Song of the } \\
\text { Jellicles" }\end{array}$ & $\begin{array}{l}\text { - Jellicle cats } \\
\text { - ball } \\
\text { - moon / } \\
\text { moonlit } \\
\text { - dance/ } \\
\text { gavotte/ jib }\end{array}$ & $\begin{array}{l}\text { - black - white } \\
\text { - morning- } \\
\text { afternoon - night }\end{array}$ & $\begin{array}{l}\text { The Jellicle cats' lives } \\
\text { are devoted to the } \\
\text { Jellicle balls held at } \\
\text { moonlit nights. }\end{array}$ \\
\hline $\begin{array}{l}\text { "Mungojerrie and } \\
\text { Rumpelteazer" }\end{array}$ & $\begin{array}{l}\text { - } \quad \text { cat / cats } \\
\text { - reputation }\end{array}$ & $\begin{array}{l}\text { - } \text { clown - } \\
\text { comedian } \\
\text { - tight rope } \\
\text { walker - acrobat }\end{array}$ & $\begin{array}{l}\text { The notorious cat } \\
\text { couple are skilled at } \\
\text { causing mischief. }\end{array}$ \\
\hline $\begin{array}{c}\text { "Old } \\
\text { Deuteronomy" }\end{array}$ & $\begin{array}{l}\cdot \text { famous } \\
- \text { many / } \\
\text { numerous } \\
\text { - prosper / } \\
\text { thrive }\end{array}$ & $\begin{array}{ll}\text { - } & \text { sleep / woken } \\
\text { - } & \text { words / spoken }\end{array}$ & $\begin{array}{l}\text { The famous cat has a } \\
\text { glorious history, and } \\
\text { now it needs not be } \\
\text { disturbed during its } \\
\text { rest. }\end{array}$ \\
\hline $\begin{array}{c}\text { "The Peke and the } \\
\text { Pollicles" }\end{array}$ & $\begin{array}{l}-\quad \text { yawn / } \\
\text { yawning }\end{array}$ & $\begin{array}{l}\text { - cat }- \text { dog } \\
\text { - fireballs - } \\
\text { blazing }\end{array}$ & $\begin{array}{l}\text { The Rumpus cat can } \\
\text { easily clear out the } \\
\text { mess caused by the } \\
\text { dogs. }\end{array}$ \\
\hline "Mr. Mistoffelees" & $\begin{array}{l}\text { - magic / } \\
\text { magician } \\
\text { - prestidigitation } \\
\text { / legerdemain } \\
\text { - deceive/ } \\
\text { deceiving } \\
\text { - clever } \\
\text { - cat/kitten }\end{array}$ & $\begin{array}{l}\text { - invention/ } \\
\text { patent } \\
\text { - magic / } \\
\text { illusion - } \\
\text { conjuring } \\
\text { - knife -fork - } \\
\text { spoon } \\
\text { - cat - fish/mice }\end{array}$ & $\begin{array}{l}\text { The magician cat can } \\
\text { play tricks using } \\
\text { familiar things } \\
\text { around. }\end{array}$ \\
\hline $\begin{array}{l}\text { "Macavity, the } \\
\text { Mystery Cat" }\end{array}$ & $\begin{array}{l}\text { - } \text { cat } \\
\text { - law } \\
\text { - } \text { crime } \\
\text { - looted/ rifles }\end{array}$ & $\begin{array}{l}\text { - break/ broken/ } \\
\text { defy - law } \\
\text { - asleep - awake } \\
\text { - think - is }\end{array}$ & $\begin{array}{l}\text { Macavity breaks the } \\
\text { law, but cannot be } \\
\text { caught because while } \\
\text { people 'think' it is } \\
\text { doing something, it } \\
\text { 'is' in fact doing } \\
\text { another. }\end{array}$ \\
\hline $\begin{array}{l}\text { "Gus, the Theatre } \\
\text { Cat" }\end{array}$ & $\begin{array}{l}\text { - } \text { cat/ kitten } \\
\text { - acted/ played } \\
\text { - theatre/ stage } \\
\text { - grandest } \\
\text { creation } \\
\text { - history }\end{array}$ & $\begin{array}{l}- \text { act }- \\
\text { performance }\end{array}$ & $\begin{array}{l}\text { Gus used to be a star } \\
\text { stage actor. }\end{array}$ \\
\hline
\end{tabular}




\begin{tabular}{|c|c|c|c|}
\hline $\begin{array}{c}\text { "Bustopher Jones, } \\
\text { the Cat about } \\
\text { Town" }\end{array}$ & $\begin{array}{l}\text { - cat } \\
\text { - fat/ has grown } \\
\text {... round/ putting } \\
\text { on weight/ } \\
\text { pounder }\end{array}$ & - cat-shrimps & $\begin{array}{l}\text { The cat continues to } \\
\text { gain weight. }\end{array}$ \\
\hline $\begin{array}{c}\text { "Skimbleshanks, } \\
\text { the Railway } \\
\text { Train" }\end{array}$ & $\begin{array}{l}\text { - } \text { cat } \\
\text { - } \text { train } \\
\text { - guard } \\
\text { - } \text { stationmaster } \\
\text { - } \text { signal }\end{array}$ & - cat / mice & $\begin{array}{l}\text { Skimbleshanks is the } \\
\text { real master of the } \\
\text { train. }\end{array}$ \\
\hline $\begin{array}{c}\text { "The Ad-Dressing } \\
\text { of Cats" }\end{array}$ & $\begin{array}{l}\text { - } \text { several/ } \\
\text { various } \\
\text { - } \mathrm{good} / \mathrm{better} \\
\text { - } \mathrm{bad} / \mathrm{worse} \\
\text { - } \mathrm{name} \\
\text { - this is this } \\
\text { - that is that }\end{array}$ & $\begin{array}{l}\text { - cat - dog } \\
\text { - cat - caviar/ } \\
\text { salmon }\end{array}$ & $\begin{array}{l}\text { Cats are like people, } \\
\text { so they need to be } \\
\text { addressed and treated } \\
\text { with respect. }\end{array}$ \\
\hline
\end{tabular}

Of course, the word "cat" is almost found in each poem, which ties all the poems of the anthology together. In addition, in Macavity, "the Mystery Cat", there is reference to Mungojerrie and Griddlebone. This again presents the whole anthology as a cohesive unit. Interestingly in the poems, cats are always paired up with mice, dogs, sunny places and household items, as these are the conventional views of cats. Thus, by juxtaposing the repeated set of words with the collocating sets, it becomes clear that the traditional views of cats are not all there is; within the feline umwelt, cats play a more significant role.

Similarly, Shawqi's poems can be seen as cohesive units of meanings, which reflect a welldesigned image of the feline umwelt. Cohesion is evident through the lexical cohesive devices that highlight the main ideas that echo through the poem. Table 2 presents some examples from the four poems.

Table 2

Examples of Lexical Cohesion in Shawqi's Poems

\begin{tabular}{|c|c|c|c|}
\hline Poem & Lexical reiteration & Lexical cohesion & The Poem Focus \\
\hline $\begin{array}{c}\text { "ضيافة قطة" } \\
\text { (Dyāfat } \\
\text { Qitah, A } \\
\text { Cat’s } \\
\text { Hospitality) }\end{array}$ & 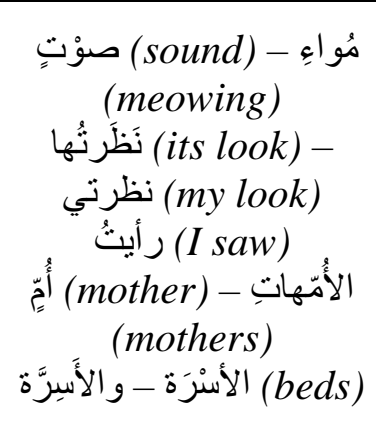 & 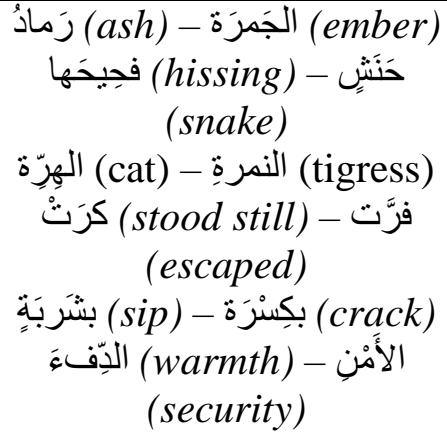 & $\begin{array}{l}\text { The speaker kindly } \\
\text { welcomes a mother cat into } \\
\text { his household. }\end{array}$ \\
\hline
\end{tabular}




\begin{tabular}{|c|c|c|c|}
\hline 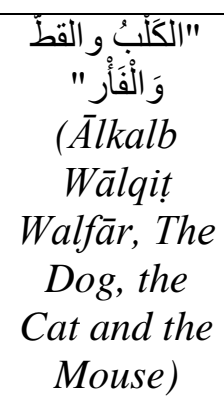 & 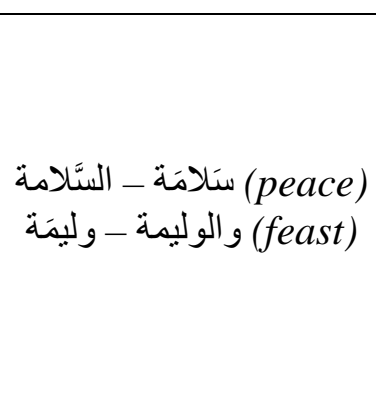 & 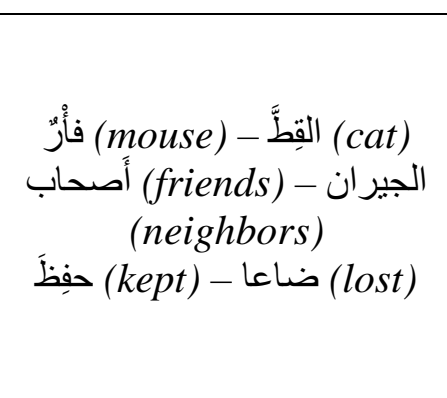 & $\begin{array}{l}\text { The poem sheds light on the } \\
\text { power relationship between } \\
\text { a dog and a cat and a cat and } \\
\text { a mouse. }\end{array}$ \\
\hline 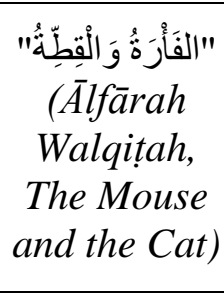 & القِطَّ - بِهِرِ - الهِرِّ (cat) (cat) & 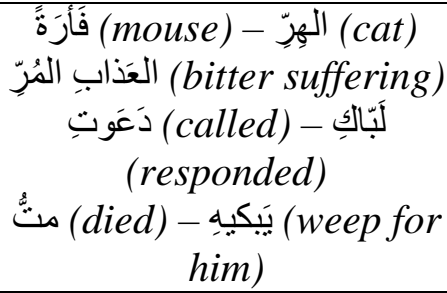 & $\begin{array}{l}\text { The poem illustrates how } \\
\text { powerful cats can be over } \\
\text { mice. }\end{array}$ \\
\hline 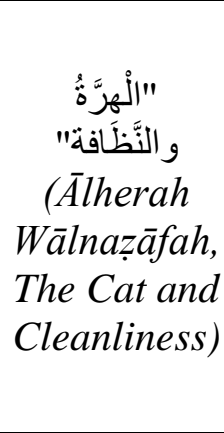 & 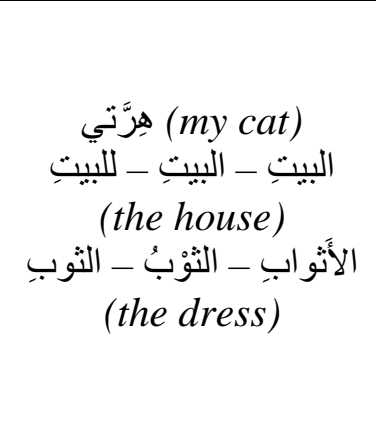 & 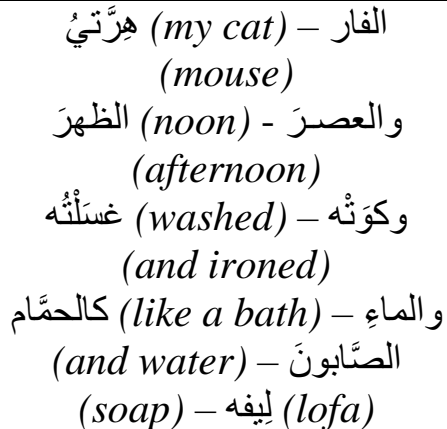 & $\begin{array}{l}\text { The cat is a clean domestic } \\
\text { pet. }\end{array}$ \\
\hline
\end{tabular}

\section{- Terms of Address}

Terms of address play a very significant role in Eliot's poems. In fact, the themes of the opening and closing poems of the anthology are mainly about how to address cats. Eliot argues that while cats are given names in the human umwelt, they have their own particular names that are reflective of their unique identity in the feline umwelt. Accordingly, throughout the poems, Eliot introduces his readers to different cats with unique names. As he refers to these cats, Eliot uses the uppercase 'C' in 'Cat'/ 'Cats', personifying the cat. In "Mr. Mistoffelees", the title "Mr." is added to further accentuate the personified status. In "The Ad-Dressing of Cats", Eliot argues that cats are like people, and so they need to be addressed as such. For example, when he meets a cat that is called by everyone as "James", he would not use this name because he knows that he is yet to form an acquaintance with the cat.

On a different note, terms of address are also important when it comes to detecting the relationship between the speaker and the audience. Throughout the poems, the speaker's voice is evident through the pronoun "I". That is, he does not opt for an invisible narrator's position; instead, the speaker assumes the role of an insider who can account for the feline umwelt. In return, the speaker frequently addresses the audience as "you". This kind of address can be seen as the speaker's attempt to involve the audience and to invite them to explore the feline umwelt. The pronoun "we" mostly strengthens the relationship between the speaker and the audience, for example, "That Cats are much like you and me/ And other people whom we find" ("The Ad- 
Dressing of Cats", L.21-22). However, at times, the pronoun "we" is used to exclude the audience. For example, in "that we usually call him just Gus." ("Gus", L.4), the first-person-plural pronoun highlights the insider status of the speaker; thus, the exclusion here can also be said to strengthen the relationship between the speaker and the audience, for it makes the speaker's account more authentic.

In Shawqi's poems, it can be argued that he assumes the role of the speaker/ narrator. In

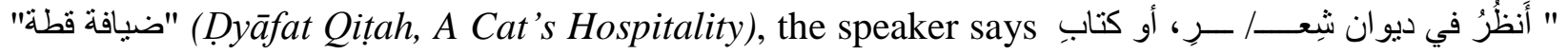
سيرة: (check a poetry anthology or a biography); the audience can easily receive the speaker as Shawqi speaking of himself. Having Shawqi as the speaker adds to the credibility of his account. Contrary to Eliot, Shawqi does not engage the audience in his poems. As for the characters of the poems, it is interesting to note that unlike Eliot's poems, the characters have no names. This may denote some unfamiliarity, which is expected as the speaker is exploring a new, strange realm. In the feline umwelt, the cat addresses the mouse as "يا كريخَ الثيمة (generous) and the mouse thinks of the cat as "سَفيهِ" (foolish). However, as the cat is perceived within the speaker's umwelt, he calls it "يا جُوَيرَنِي" (my cat); this accents the power relationship in favor of the speaker.

Another vital remark regarding the terms of address has to do with gender. In Eliot's anthology, only one poem has a female cat. In "Mungojerrie and Rumpelteazer" and "The Jellicles" the cats are referred to as "they", so the gender maintains a neutral status. As for the remaining 11 poems, the cats are referred to as "he". It can be argued here that since "Gumbie" is associated with cat's domestic arena while the rest of the poems take place in the public sphere, "ضيافة قطة" (Dyāfat Qițah, A Cat’s Hospitality) and "هرني والنظافة" (Ālherah Wālnazāfah, The Cat and Cleanliness) are females because they are associated with motherhood and domesticity, respectively. On the other hand, male cats are those seen in the public sphere encountering mice

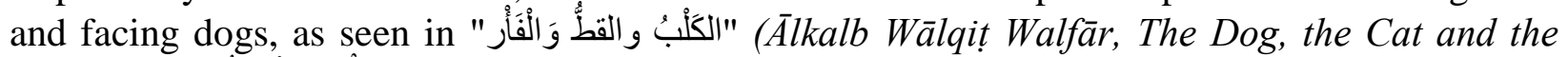

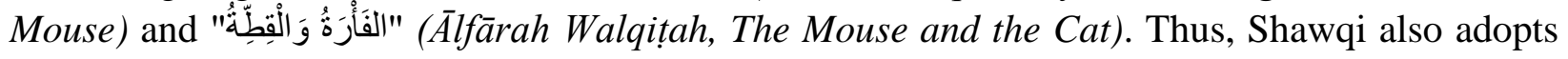
traditional gender roles in ascribing roles to the feline umwelt.

\subsection{Poetic Devices}

\section{- Parallel Schemes: Rhyme}

As Leech (1991) suggests, rhyming schemes foreground the rhymed pairs against the rest of the lines. It can be further argued, though, that when a poem follows a pattern, rhyming pairs also foreground the poetic lines. As the ear detects the rhyme scheme of the poem, it begins to wait for it at the end of each line. In this way, Eliot employs rhyme in his poems; all his poems follow an organized rhyme which can be seen as a tool of foregrounding the topic in question. Breaking the pattern is another tool of foregrounding because the deviation alarms the ear to the broken rhyme. This is evident in "The Naming of Cats" when Eliot produces a half-rhyme in "over""discover". The broken rhyme calls attention to the impossibility of understanding a cat's identity even if much research is conducted. 
In addition, Eliot employs internal rhyme in "Bustopher Jones, the Cat about Town" and "Skimbleshanks, the Railway Cat". In "Bustopher Jones, the Cat about Town", the internal rhyming pairs foreground Bustopher Jones' physical appearance and habits. For examples, pairs, such as "bounder"-“pounder", "way"-“day", "noon"-“soon" and "preserved"-“observed", underscore the cat's weight problem, the way it goes about its day and the distinguished status it observes. Similarly, in "Skimbleshanks, the Railway Cat", rhyming pairs, like "appear"-"rear", "control"-"patrol", "neat"-“sheet”, "paces"-“faces", "winking"-“thinking”, "light"-“bright" and "politely"-"brightly", highlight the role Skimbleshanks plays on the train and the control it maintains to make sure everything is perfect.

"ضيافة قطة" In contrast, Shawqi employs different rhyming schemes in his poems. In (Dyāfat Qițah, A Cat's Hospitality), Shawqi does not follow an organized rhyme; however, instances of rhyming pairs across the poem can easily be spotted. For example, the rhyme between

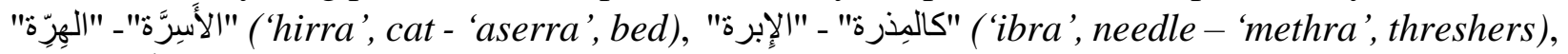
and "مَجْمَرَتي" - "بستُرُني" ('besutraty', my coat- 'begamraty', my heater) draw attention to these parallel pairs. That is, the cat's place is identified as under the beds; it uses its body parts as weapons (the whiskers as needles and the tails as threshers); it is up to the speaker to provide security to the cat using his own belongings such his heater and his coat.

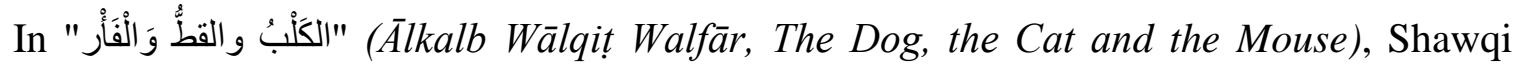
employs a Leonine verse in which the final rhyme of the first half of the line agrees with the final

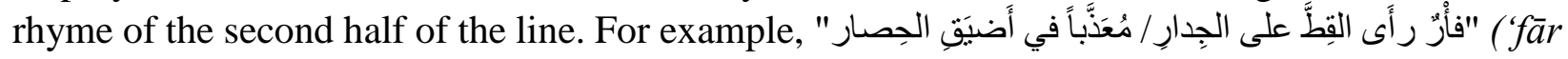
$\bar{a} \bar{a}$ àlqit 'la ālğidār/ mu 'dabān fy ādyaq älhișār', a mouse saw the cat on the wall/ suffering in the narrowest trap). This use of rhyme adds a musical effect to the entertaining story narrated by the

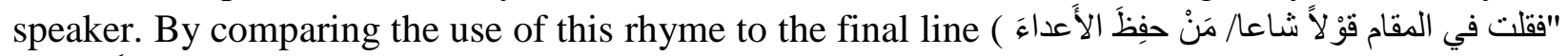

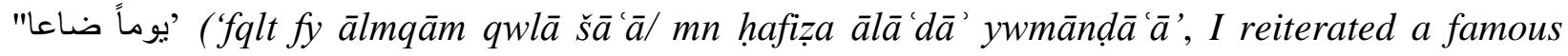
proverb/ those who befriend enemies lose), the poem can be perceived as a fable with a moral at

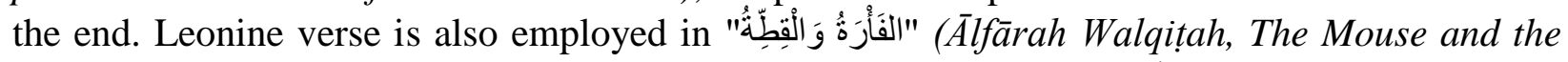
Cat); the musical effect corresponds to the opening word of the poem: "سَِعَتُُ " (I heard). It can be argued, thus, that as the poet finds the incident between the cat and the mice entertaining, he tries

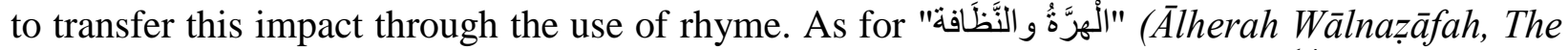

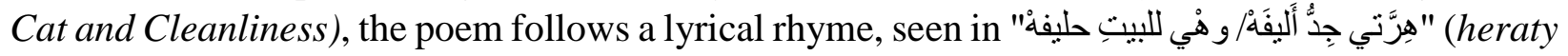
ğadun ālyfh/wahiya llbayt hlyfah, my cat is very friendly/it's an ally to the house). Since the poem is part of an anthology addressed to children, the musical effect is necessary to replicate nursery rhymes and to appeal to children's taste of poetry and songs.

\section{- Tropes: Metaphors}

Tropes are mainly employed to smooth the translation process of the feline umwelt. Both Eliot and Shawqi make extensive use of metaphors where the cat characters are associated with human activities. It is true that in poetic conventions, this is referred to as 'personification'; however, Leech (1991) opts for the more general word 'metaphor' that accounts for the translation of meaning. 
Eliot mainly relies on implicit comparisons to translate his vision of the feline umwelt. His metaphors can be categorized into associating cats (TENOR) with VEHICLES of mental abilities and human actions, on the one hand, and people or other creatures, on the other. For examples, across the poems, Eliot's cats 'cherish', 'know', 'meditate', 'engage in thoughts', 'contemplate' and 'rejoice'. They also 'teach', 'create', 'sing', 'dance', 'practice', 'speak', 'act', 'extemporize' and 'understudy'. Cats' skills are showcased by being compared to 'comedians', 'acrobats', 'plausible fellows', 'Napoleon' and 'master criminals'. They are compared to 'lions' and 'monsters'.

In a similar vein, Shawqi's depiction of the feline umwelt is brought closer to the reader by comparing cats (TENOR) to vehicles of cognitive abilities, human actions, other animals,

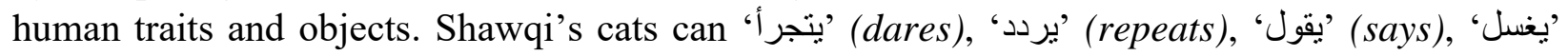
(washes), and 'يكوي' (irons); they are also capable of 'التفكير' (thinking). Just as Eliot's cats were compared to 'lions', In Shawqi's "ضيافة قطة" (Dyāfat Qitah, A Cat's Hospitality), the cat assumes

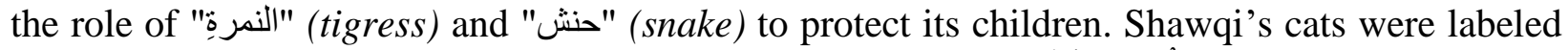

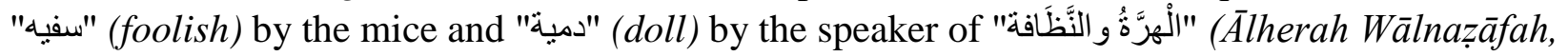
The Cat and Cleanliness).

\section{Discussions and Conclusion}

The study attempted to detect Eliot and Shawqi's mind-style conceptualization of the feline umwelt. Exploring their mind-style mainly depended on tracing the linguistic patterns followed across the poems. It is interesting to note that Eliot and Shawqi take their audience to different milieus; while some fall in the human umwelt, others are situated in the feline umwelt. In their accounts, both poets adopt many similar tools to convey their visualization of the feline umwelt. They depend on concrete nouns to account for the entities associated with the cats and their words; they devote the abstract nouns to reporting feelings and status that can only be perceived via imagination. Eliot and Shawqi's poems are dominated by dynamic transitive verbs that prove the effective influential roles cats play in the feline umwelt. Poems are primarily delivered through declarative statements, where lexical cohesion plays a crucial role in tying the poetic lines and highlighting the depictions in focus. The speakers in Eliot and Shawqi's poems are explicitly referred to through the personal pronouns, which could be seen as an attempt to present a more trustworthy account of the feline umwelt. To draw the unknown umwelt closer to the readers' imagination, the poets employ metaphors that mostly associate cats with human abilities and activities.

On the other hand, Eliot and Shawqi's overall depiction of the feline umwelt differs in more ways than one. Although both poets establish power relationships, Shawqi stresses the hierarchy placing humans above cats. In "ضيافة قطة" (Dyâfat Qiṭah, A Cat's Hospitality) and الْهرَّة و النَََّافةة" (Álherah Wālnazâafah, The Cat and Cleanliness), the speaker clearly manifests power and authority over the cat. Cats are also placed under dogs in the power triangle. They can only exert power and control over mice and fleas. In contrast, in Eliot's poems, people are helpless against cats' uncontrollable behavior. Mungojerrie, Rumpelteazer and Macavity's actions, for example, prove the cats' abilities to cause mischief and run away with it. Similarly, Skimbleshanks is the 
real master of the midnight train. As for Rumpus Cat, it is seen as more powerful than the pekes and the Pollicles dogs.

In addition, even though Eliot and Shawqi transfer the gender ideology to their mind-style depiction of the feline umwelt, they associate cats with different roles. In Eliot, cats are seen as mischievous and are associated with crime in more than one poem. Eliot also shows that cats are lazy and they just like to 'sit' in 'sunny', 'warm' places. In only two accounts are Eliot's cats seen as the source of order: "The Old Gumbie Cat" and "Skimbleshanks, the Railway Cat". Shawqi, on the other hand, presents cats as pious creatures who are always reciting prayers. They are also seen as mothers and as clean domestic pets. In Shawqi's poems, cats are proven vicious only when they assume their predator roles in search for mice or when they want to protect their children.

In conclusion, it can be argued that while both poets succeed in acknowledging the muchignored feline umwelt, their mind-style conceptualization is much influenced by culture and ideology. In his poems, Eliot asks his audience to acknowledge the feline umwelt, but at the same time, cats are still seen through the stereotypical lens of idleness and mischief. Similarly, Shawqi ventures into the feline world, but his depiction reflects Egyptian views of cats as archenemies of mice and as clean and devout animals. Thus, Eliot and Shawqi's views of the feline umwelt is still governed by their subjective views and their imaginative abilities. 


\section{References}

Berthoz, A. (2009). The human brain 'projects' upon the world, simplifying principles and rules for perception. In A. Berthoz \& Y. Christen (Eds.). Neurobiology of "umwelt": How living beings perceive the world. (pp. 17-28). Springer.

Eliot, T. S. (2001). Old possums’ book of practical cats. Faber and Faber.

Fowler, R. (1977). Linguistics and the novel. Methuen.

Halliday, M. A. K. (1971). Linguistic Function and Literary Style: An Inquiry into the Language of William Golding's The Inheritors. In S. Chatman (Ed.). Literary style: A symposium. (pp. 330-65). Oxford University Press.

Halliday, M. A. K., \& Hassan, R. (1976). Cohesion in English. Longman.

Herman, D. (2016). Building More-Than-Human Worlds: Umwelt modelling in animal narratives. In J. Gavins \& E. Lahey (Eds.). World building: Discourse in the mind. (pp. 53-70). Bloomsbury Academic.

Lakoff, G. and Johnson, M. (1980). Metaphors we live by. University of Chicago Press.

Leech, G. (1991). A Linguistic guide to English poetry. Longman. (15 ${ }^{\text {th }}$ edition).

Leech, G., \& Short, M. (2007). Style in fiction: A linguistic introduction to English fictional prose. Pearson Education Limited. ( $2^{\text {nd }}$ edition).

Pollman, I. (2013). Invisible Worlds, Visible: Uexküll's Umwelt, Film, and Film Theory. Critical Inquiry, 39(4), 777-816. https://www.jstor.org/stable/10.1086/671356

Semino, E. (2002). A cognitive stylistic approach to mind style in narrative fiction. In E. Semino \& J. Culpeper (Eds.). Cognitive stylistics: Language and cognition in text analysis. (pp. 95-122). John Benjamins.

Singer, W. (2009). The brain's view of the world depends on what it has to know. In A. Berthoz \& Y. Christen (Eds.). Neurobiology of "umwelt": How living beings perceive the world. (pp. 39-52). Springer.

Uexküll, J. V. (2010). A foray into the worlds of animals and humans: With a theory of meaning. (J. D. O’Neil, Trans.). University of Minnesota Press. (Original work published 1934).

$$
\text { شوقي، أ. (2012). الشوقيات . مؤسسة هنداوي للتعليم والثقافة. }
$$

